\title{
Mathematics Preparation in the World: Similarities and Differences
}

\author{
Wes Grebski, Ph.D. ${ }^{1}$, The Pennsylvania State University,USA,wxg3@psu.edu \\ Michalene Grebski, M.A. ${ }^{2}$, Rosemont College, USA, megrebski@gmail.com
}

\begin{abstract}
This paper outlines the results of an initial study conducted by the authors which compares the Math preparation of incoming freshman Engineering students. This baseline comparison was made by measuring the level of Math preparation of fifty randomly selected students in China, Peru, Poland and the United States. The study was done with the objective of looking at each countries experiences and identifying the best practices which produce the highest success rate in teaching Mathematics. The authors of this presentation would like to identify those best practices and implement them into the teaching of Mathematics at Penn State Hazleton. Increasing the students' success rate in Mathematics would also increase the retention rate in the Engineering program at Penn State Hazleton. In addition to comparing the level of Math preparation, data has been collected on student and teacher perception and attitude toward the teaching and learning of Mathematics. Using the baseline data, the authors of this presentation have outlined limited conclusions and suggestions. In addition, they have also outlined further areas of academic study to collect more statistically valid data.

Keywords- Math remediation; math preparation; retention
\end{abstract}

Digital Object Identifier (DOI):

http://dx.doi.org/10.18687/LACCEI2016.1.1.043

ISBN: 978-0-9822896-9-3

ISSN: $2414-6390$

$14^{\text {th }}$ LACCEI International Multi-Conference for Engineering, Education, and Technology: "Engineering Innovations for Global Sustainability”, 20-22 July 2016, San José, Costa Rica. 


\title{
Mathematics Preparation in the World: Similarities and Differences
}

\author{
Wes Grebski, Ph.D. ${ }^{1}$, The Pennsylvania State University, USA,wxg3@psu.edu \\ MichaleneGrebski, M.A. ${ }^{2}$, Rosemont College, USA, megrebski@gmail.com
}

\begin{abstract}
This paper outlines the results of an initial study conducted by the authors which compares the Math preparation of incoming freshman Engineering students. This baseline comparison was made by measuring the level of Math preparation of fifty randomly selected students in China, Peru, Poland and the United States. The study was done with the objective of looking at each countries experiences and identifying the best practices which produce the highest success rate in teaching Mathematics. The authors of this presentation would like to identify those best practices and implement them into the teaching of Mathematics at Penn State Hazleton. Increasing the students' success rate in Mathematics would also increase the retention rate in the Engineering program at Penn State Hazleton. In addition to comparing the level of Math preparation, data has been collected on student and teacher perception and attitude toward the teaching and learning of Mathematics. Using the baseline data, the authors of this presentation have outlined limited conclusions and suggestions. In addition, they have also outlined further areas of academic study to collect more statistically valid data.

Keywords-

Math remediation; math preparation; retention
\end{abstract}

\section{INTRODUCTION}

Most Engineering programs everywhere are struggling with recruitment and retention issues. It becomes extremely harder to recruit well-prepared students. Majority of the students entering the freshman year have insufficient math background and require extensive remediation. Even with remedial courses being available, the retention rate is very low. The retention rate at Penn State Hazleton is $25 \%$. In order to improve the success rate in math and improve retention, a comparison study was conducted. Four different countries representing different geographical regions of the world were selected for this initial study; United States representing North America, Peru representing South America, Poland representing Europe and China representing Asia. There are significant differences between the primary and secondary education systems in those countries. The approach to teaching mathematics can also be very different and produce different results. The purpose of this initial study was to provide a baseline for the methods of teaching mathematics. In addition, this initial study was conducted to analyze why that success rate is different and what can be done to learn from each other's experiences.

\section{COMPARISON OF MATH EDUCATION}

An identical math survey was given to incoming freshman Engineering students in four geographical regions of the world. The survey was administered in the students' native language. A forty minute time interval was given to complete the survey. Students had to complete thirteen math problems on a precalculus level (algebra, trigonometry). Students were taking the survey voluntarily and were made aware of the purpose. All of the math problems were scored by the same person. The results of the surveys are shown in Table 1.

TABLE 1. Results of Math test: \% of the right answers

\begin{tabular}{|c|c|c|c|}
\hline China & Peru & Poland & $\begin{array}{c}\text { United } \\
\text { States }\end{array}$ \\
\hline 86 & 81 & 79 & 75 \\
\hline
\end{tabular}

In addition to the math quiz, every student was asked to fill-out a questionnaire containing seven questions. This was done for the purpose of assessing the students' perspective on their accomplishment as 
well as students' attitude towards studying mathematics. A similar questionnaire was given to the Math teachers for the purpose of comparingthe teachers' perception with the students' perception on the issues listed below:

-Who deserves credit for the students' success?

-Who is to blame for the students' failure?

-What is the main reason for a student's failure?

-What affects the students' self-esteem in the study of Mathematics?

-What factors contribute to the success or failure in the study of Mathematics?

-What is the student and teacher perception on Math preparation?

All of the teachers' and students' surveys were tabulated by the authors of this presentation. The results are shown in Table 2 to Table 6 , inclusively.

TABLE 2. Credit for student success: student and teacher perception

\begin{tabular}{|l|c|c|}
\hline Country & $\begin{array}{c}\text { Student Perception } \\
\text { (Student } \\
\text { Contribution/Teacher } \\
\text { Contribution) }\end{array}$ & $\begin{array}{c}\text { Teacher Perception } \\
\text { (Student } \\
\text { Contribution/Teacher } \\
\text { Contribution) }\end{array}$ \\
\hline China & $70 \% / 30 \%$ & $60 \% / 40 \%$ \\
\hline Peru & $80 \% / 20 \%$ & $70 \% / 30 \%$ \\
\hline Poland & $70 \% / 30 \%$ & $50 \% / 50 \%$ \\
\hline $\begin{array}{l}\text { United } \\
\text { States }\end{array}$ & $80 \% / 20 \%$ & $50 \% / 50 \%$ \\
\hline
\end{tabular}

TABLE 3. Who is to blame for student failure?

\begin{tabular}{|l|c|c|}
\hline Country & $\begin{array}{c}\text { Student Perception } \\
\text { (Student } \\
\text { Contribution/Teacher } \\
\text { Contribution) }\end{array}$ & $\begin{array}{c}\text { Teacher Perception } \\
\text { (Student } \\
\text { Contribution/Teacher } \\
\text { Contribution) }\end{array}$ \\
\hline China & $60 \% / 40 \%$ & $70 \% / 30 \%$ \\
\hline Peru & $50 \% / 50 \%$ & $80 \% / 20 \%$ \\
\hline Poland & $50 \% / 50 \%$ & $90 \% / 10 \%$ \\
\hline $\begin{array}{l}\text { United } \\
\text { States }\end{array}$ & $40 \% / 60 \%$ & $90 \% / 10 \%$ \\
\hline
\end{tabular}

The collected data shows the teachers feel that they deserve significant credit for the students' success. There was a $30 \%$ to $50 \%$ range. However, at the same time, they are not willing to take the blame for the students' failure. There was a $10 \%$ to $30 \%$ range. (Success has many fathers; failure does not.) All most al of the teachers believe that the students entering the class are poorly prepared which may result in class failure. However, students believe that they deserve credit for success; $70 \%$ to $80 \%$ range, but they also feel that they deserve a much lower blame for their failure; $40 \%$ to $60 \%$ range. 
TABLE 4. Factors Contributing to Success in Mathematics: student and teacher perception

1=Most important; $2=$ Important; $3=$ Least important

\begin{tabular}{|l|l|l|l|l|l|l|}
\hline Country & \multicolumn{2}{|l|}{ Natural Ability } & \multicolumn{2}{l|}{ Hard Work } & \multicolumn{2}{l|}{ Motivation } \\
\cline { 2 - 7 } & $\begin{array}{l}\text { Student } \\
\text { Perception }\end{array}$ & $\begin{array}{l}\text { Teacher } \\
\text { Perception }\end{array}$ & $\begin{array}{l}\text { Student } \\
\text { Perception }\end{array}$ & $\begin{array}{l}\text { Teacher } \\
\text { Perception }\end{array}$ & $\begin{array}{l}\text { Student } \\
\text { Perception }\end{array}$ & $\begin{array}{l}\text { Teacher } \\
\text { Perception }\end{array}$ \\
\hline China & 2 & 3 & 1 & 1 & 3 & 2 \\
\hline Peru & 1 & 2 & 2 & 1 & 3 & 1 \\
\hline Poland & 1 & 2 & 3 & 1 & 2 & 3 \\
\hline $\begin{array}{l}\text { United } \\
\text { States }\end{array}$ & 1 & 2 & 3 & 1 & 2 & 3 \\
& & & & & & \\
\end{tabular}

There are very different perceptions of contributing factors leading to success and failure in mathematics. Teachers in the four surveyed countries were listing hard work as the most important factor. However, students felt that natural ability and motivation was more important than hard work. Only the students in China listed hard work as the most important factor in determining student success or failure. At the same time students in Poland and the United States listed hard work as the least important factor in determining their lack of success. Peruvian students were in the middle.
TABLE 5. Factors contributing to failure in Mathematics: student and teacher perceptions

\section{$1=$ Most important; 2 = Important; 3 = Least important}

\begin{tabular}{|l|l|l|l|l|l|l|}
\hline Country & \multicolumn{2}{|l|}{ Lack of Natural Ability } & \multicolumn{2}{l|}{ Lack of Hard Work } & \multicolumn{2}{l|}{ Lack of Motivation } \\
\cline { 2 - 7 } & $\begin{array}{l}\text { Student } \\
\text { Perception }\end{array}$ & $\begin{array}{l}\text { Teacher } \\
\text { Perception }\end{array}$ & $\begin{array}{l}\text { Student } \\
\text { Perception }\end{array}$ & $\begin{array}{l}\text { Teacher } \\
\text { Perception }\end{array}$ & $\begin{array}{l}\text { Student } \\
\text { Perception }\end{array}$ & $\begin{array}{l}\text { Teacher } \\
\text { Perception }\end{array}$ \\
\hline China & 3 & 3 & 1 & 1 & 2 & 2 \\
\hline Peru & 2 & 3 & 3 & 1 & 1 & 2 \\
\hline Poland & 1 & 2 & 3 & 1 & & 3 \\
\hline $\begin{array}{l}\text { United } \\
\text { States }\end{array}$ & 1 & & & & & \\
\end{tabular}

There are some cultural differences for taking responsibility for success and failure. As a human being we have a tendency to look for excuses and put blame elsewhere. Blaming natural ability releases us from responsibility therefore making nature or a supernatural being responsible for out failure.This attitude can be nurtured by parents and family members. Very often students are expected to be gifted and become successful in mathematics based on their innate ability, for example, (s)he was so smart that when (s)he was going to high school (s) he got straight "A"'s and (s)he did not have to do any work. Further research would need to be done to draw more reliable conclusions. It would be important to see for what children and adolescents receive praise in the four countries where the authors have done the surveys and made the comparisons. Do students receive more praise for hard work ethic or natural ability? Are parents and family members more proud of natural ability of the student/their child or a strong work ethic? 
TABLE 6. Self-perception on Math preparation

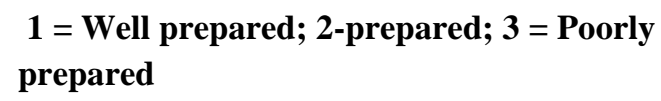

\begin{tabular}{|l|c|c|}
\hline Country & Student Perception & $\begin{array}{c}\text { Teacher } \\
\text { Perception }\end{array}$ \\
\hline China & 2 & 2 \\
\hline Peru & 2 & 2 \\
\hline Poland & 1 & 3 \\
\hline $\begin{array}{l}\text { United } \\
\text { States }\end{array}$ & 1 & 3 \\
\hline
\end{tabular}

Students were asked the question if they feel prepared in Mathematics to compete with their counterparts in the job market.Teachers were also asked the same question. The teachers believed that their students were either prepared or poorly prepared. Their perception coincides with the results of the Math test. Students, however, believed that they are either prepared (China, Peru) or wellprepared (Poland, United States). Student results as far as Math preparation does not coincide with the results of the Math test. Students from Poland and the United States feel well-prepare regardless of their performance on the Math test.

\section{CONCLUSIONS}

The limited study which was conducted indicated that the highest achievement in mathematics takes place in China followed by Peru, Poland and the United States. There is a correlation between mathematics performance and the core beliefs in "prescription for success". In China hard work seems to be the prescription for success. In Poland and the United States natural ability is being viewed (especially by the students) as a decisive factor. The results for Peru were in the middle. Self-perception of student achievement is inversely proportional to their knowledge of mathematics. In China and Peru students think that they are prepared to compete with their counterparts in the world. Students in Poland and the United States think that they are wellprepared to compete even though their math performance does not reflect that. Some further research would have to be done to generate more statistically valid conclusions. The recommendation at the present time would be to promote a hard work ethic and discourage the natural ability mentality and excuse.

\section{REFERENCES}

[1] Beaton, A.E. et al. "Mathematics Achievement in the Final Year of Secondary School: IEA International Mathematics and Science Study”. TIMSS, 1998.

[2] Beaton, A.E. et al. "Mathematics Achievement in the Middle Years: IEA's International Mathematics and Science Study. TIMSS, 1996.

[3] Brown, Peter C., Henry L. Roediger, III and Mark A. McDaniel. Making It Stick: The Science of Successful Learning. Cambridge, MA: Harvard University Press, 2014.

[4] Chen, Xianglei. STEM Attrition: College Students' Paths Into and Out of STEM Fields. (NCES 2014-001). Washington, DC: National Center for Education Statistics, Institute of Education Sciences, U.S. Department of Education, 2013.

[5] Farrington, Camille A. Academic Mindsets as a Critical Component of Deeper Learning. A White Paper prepared for the William and Flora Hewlett Foundation. April 2013.

[6] George, Melvin D., et al., (20 September 2004). "Shaping the Future: New Expectations for Undergraduate Education in Science, Mathematics, Engineering, and Technology." National Science Foundation. NSF 96-139. Part I. [Online]. Available: http://www.ehr.nsf.gov/ehr/due/documents/review/9613 9/start.htm

[7] George, Melvin D., et al., (20 September 2004). "Shaping the Future: New Expectations for Undergraduate Education in Science, Mathematics, Engineering, and Technology." National Science Foundation. NSF 96-139. Part II. [Online]. Available: http://www.ehr.nsf.gov/ehr/due/documents/review/9613 9/start.htm 
[8] George, Melvin D., et al., (20 September 2004). "Shaping the Future: New Expectations for Undergraduate Education in Science, Mathematics, Engineering, and Technology." National Science Foundation. NSF 96-139. Part III. [Online]. Available: http://www.ehr.nsf.gov/ehr/due/documents/review/9613 9/start.htm

[9] Kim, George D. High-Impact Educational Practices: What They Are, Who has Access to Them, and Why They Matter. Washington, D.C.: Association of American Colleges and Universities, 2008.

[10] President's Council of Advisors on Science and Technology. Engage to Excel: One Million Additional College Graduates and Degrees in Science, Technology, Engineering and Mathematics. Washington, DC, 2012.

[11] "Pursuing Excellence: A Study of U.S. Fourth GradeMathematics and Science Achievement in
International Context," U.S. Department of Education, National Center for Education Statistics, 1998.

[12] "Pursuing Excellence: A Study of U.S. Fourth Grade Mathematics and Science Achievement in International Context." U.S. Department of Education, National Center for Education Statistics, 1997.

[13] Rosser, James M., et al. (20 September 2004). "Shaping the Future, Volume II: Perspectives on Undergraduate Education in Science, Mathematics, Engineering, and Technology." National Science Foundation. NSF 98128. [Online]. Available: http://www.nsf.gov/pubs/1998/nsf98128/nsf98128.htm

[14] U.S. Department of Education, National Center for Education Statistics, "Mathematics Curriculum and College Enrollment," The Condition of Education 2001, Indicator 24, NCES 2001-072, Washington, DC: U.S. Government Printing Office, 2001. 